\title{
Effect of Academic \& Personality Development Activities on Competitiveness of Business Schools: An Empirical Study through the Lens of Islamic Perspective
}

\author{
Irum khattak \\ Islamia college peshawar (chatered university) \\ Qadir Bakhsh Baloch \\ Abdul Wali Khan University \\ Gohar zaman \\ Women university Swabi, Pakistan
}

\begin{abstract}
The study intended to investigate the effect of academic and personality development activities on competitiveness of business schools through the lens of Islamic perspective. The features of academic \& personality development activities of competitive business schools from modern literature were studied in the light of Islamic perspective. Regression analysis was used to test the hypothesis. Data was collected from a sample of 354 students through structured questionaire. The study found that Islam supports businesses education and provides a comprehensive framework that embodies moral and social values leading to a prosper society in long-term. The activities of academic and personality development in modern literature to increase the competitiveness of business schools are supported by Islamic perspective as far as it is within Islamic boundaries. Positive relation was found between academic and personality development activities and competitiveness of business schools from students' perspective. Future studies are directed to cover other activities required for competitiveness of business schools and its relevance from Islamic perspective.
\end{abstract}

Keywords: Competitiveness, Business schools, Academic, Personality, Activities, Social, Islam.

1. irumkhattak2013@gmail.com,

2.9bbaloch@awkum.edu.pk,

3. goharzaman@icp.edu.pk 


\section{INTRODUCTION}

Business schools are the higher education intuitions that impart business education. It gives mangers, entrepreurs and businenesman to a soceity. It lies down a foundation for competitive markets, skilled human resource and overall competitiveness of a nation (Koh, 2012; Musselin, 2018). Higher education plays an important role in national competitiveness of a country for the reason that it is the source of knowledge generation and delivers knowledge to the society (World Bank, 2000). The world Global competitiveness report considered higher education as fifth pillar of competitiveness in "Global competitiveness index (GCI)" that corresponds to the enrollment rates in higher education as well as quality of education as appraised by the business community (World Economic Forum, 2014). It reflects the importance of business education in the context of high demand for knowledge workers evident from the fact that the social sciences, business, and law are the most popular programs around the world (World Bank Group, 2015). Business \& management education through human capital development is a factor that influences the other activities of competitiveness of nation such as labor market efficacy, business sophistication, technological readiness and innovation. The central theme of higher education has become to nurture students as a human capital that acquires education, skills, knowledge and life- long learning (Contardo \& Wensley, 2004; World Economic Forum, 2014). This is also the reason that business schools are highly skeptical for producing inefficient leaders and unethical behavior of business world. Worldwide business schools are being criticized for corporate failures that they are not imparting appropriate education. The strategy guru, Mintzberg declares less-than-relevant MBA curriculum as main culprit for the situation (Bennis \& O'Toole, 2005). Bennis and O'Toole (2005) also view that today's business schools are loosing their ways.

In comparison to the world, Pakistan has very low scores over the GCI aspects of competitiveness. According to the World Economic Forum (2014), the most problematic factors for doing business in Pakistan also involves inadequately educated workforce and poor work ethics in national labor force. The workforce has poor work ethics despite the fact that the majority of population in Pakistan consists of Muslims and Islam is the religion of ethics. It is the only religion that covers every sphere of life. Islam is rarely studied and taught in the context of modern times to help Muslims in practicing Islam in every sphere of life such as education, politics and economy etc. There is always kept a gap between modern literature and Islamic studies and hence the real essence of divine guidance is not enjoyed by Muslims. The alarming voice of modern world of unethical behavior of business leaders can be solved if Islamic perspective of business is studied and instilled in minds of student in early age of studies in business schools. Islamic perspective of business are highly superior to modern literature for the fact that it is not based on profit as prime objective as in free Friedman (1962) or prevailing secular system. It is based on fear and reward from the creator that rejects the materialist view of business (Rice, 1999). Moreover, Islam believes in collective development of society than individualistic goals (Musah, 2011).

In this context, more studies are required to explore the viability of modern ways in

Page | 183 
light of Islamic perspective and find solutions for humanity from the divine sources. Academic and personality development activities imparted in business schools can be helpful for the development of socially responsible knowledge worker. Thus, it is highly required to study the academic and personality development activities of competitive business schools of the world that affect competitiveness of business schools. Moreover, it is also required to check viability of factors of competitiveness of business schools given in modern literature from Islamic perspective to achieve a holistic view of knowledge. There is a misconception that Islam inhibits modernism, new ways of learning and self-development although Islamic perspective provides a superior framework of modernism and modern world problems. The study is intended to address the issue for the reason that prevailing knowledge and globalization driven era will not allow to anticipate the future needs of jobs but efforts are required for competitive quality of education that instill lifelong learning capacity in the next generation to cope with present and future challenges.

\section{Research Objectives}

The objectives of this study are:

1. To explore the feautres of academic and personality development activities from modern literature and explore its viability from Islamic perspective.

2. To analyze the effect of academic and personality development activities on competitiveness of business schools.

\section{LITERATURE REVIEW}

Literature review covers the Islamic perspective and modern literature on academic and personality development activities. The features identified in modern literature are discussed from Islamic perspective to explore its viability in Islamic context.

\section{Islamic Perspective on Business and Management:}

Islamic is not only a religion but a way of life that provides a complete guideline to every activity of human life. It ranges from personal to social life and provide humankind with such core principles that covers every sphere of life. The misconception about Islam that it provides hindrance to the economic activities is erroneous (Gumusay, 2015). Business in Islam is given due importance but unlike western individualistic philosophy of solely profit oriented goal, it emphasizes on society welfare (Thaib \& Chepa, 2014). The importance of business in Islam is evident from fact the Prophet Muhammad (PBUH) was involved in business. The prophet said: "The truthful merchant is rewarded (by being ranked) on the Day of Resurrection with prophets, veracious souls, martyrs and pious people" (Tirmidhi, 1130).

Islam set a framework for ethical business with first thing that ownership belongs to Allah (Qur'an 24:33) and humans as caliphs, trustees or viceregents (Qur'an 2:30; 57:7). Islam prohibits false measuring (Qur'an 55:9; 17:35) or lying (Qu'ran 6:152; $33: 70 ; 17: 36$ ). And fraud is strictly prohibited (Qur'an 83:1-4). Certain products such as pork (Qur'an 2:173), alcohol or gambling (Qur'an 5:90) are forbidden that damage the societies. Moral directives in doing business are given in Islam. Muslims 
are directed to write it justly when money is lended for a particular period, the one who can write it must not refuse to document it (Qur'an 2: 282). Furthermore, Islam encourages social responsibility from businesses. It is directed to not devour your property among yourselves wrongly; but trade by mutual consent (Qur'an, 4.29) and hoarding of wealth is prohibited (Qur'an 3:180; 9:34). Zakat is imposed on wealth in Islam imposing social responsibility on businesses as well. Islam directs to spend out of what Allah has provided them with, both secretly and openly (Qur'an 14: 31) emphasizing on charity and charitable work.

Overall, businesses and Islamic economic system is socially oriented but it should not be falsely interpreted for a compromise in profitability. It directs toward a sustainable growth of society as whole to provide mutual benefits to all parties (Thaib \& Chepa, 2014).

\section{Competitive Features of Academic \& Personality Development Activities in Modern Literature}

Business schools are meant to create futures businesses, leaders, managers and entrepreneurs in a country. Successful leaders and mangers are nurtured in business school if their curriculum involves competitive learning, social and developing activities. The term academic activities are confined to the courses (Abdullah, 2006), strategies to implant employability across the whole curriculum, work related modules, problem based and work related learning, skills identification and curriculum audit (Milner, Cousins, \& McGowan, 2016). Personality development is a broad spectrum that includes all those activities which are meant to groom students other than coursework. It includes the ethical and societal activities that give a sense of responsibility to students that as managers they have to contribute to the society. Extracurricular activities are equally important for employability because engagement in extracurricular activities provide rich experience of learning which occurs outside the curriculum that makes students feel as a part of the institute and also develop their personal confidence and communication skills (Milner, 2016). The features of competitive academic and personality development activities isolated from literature are summarized in Figure 1. 


\section{Competitive Academic Activities}

Variety in programs and electives

Flexible programs such as classes in the evenings and at weekends or online study arrangement on certain courses etc. so create work life balance

Providing market relevant course curriculum \& review it frequently

Plagiarism policy

Current material and readings are in class

E-business topics are included throughout curriculum

Emphasizing on topics as ethics in business, entrepreneurship and ventures, global business management etc.

Industry oriented assignments or industrial related projects as part of degree completion

Observe strict attendance in classes

New ways of teaching methodology aided with technological tools in curriculum such as live case study methods, advanced computer simulation methods, learning through games and simulated trading areas

Teaching modern computer skills useful on job

Efforts to include entrepreneurship and new ventures development in courses.

Small size of class

\section{Competitive Personality Development Activities}

- Activities to develop leadership skills and promote teamwork in students.

- Activities to provide opportunities for analytical, interpersonal and soft skill development.

Counseling for students such as stress management, time management, art of living etc.

Efforts to include diversity through foreigners, females, national minorities and various cultures students in classes

- Promoting students for association with voluntary projects

- $\quad$ Engagement of business school in fulfilling its obligations to society by investing in the local community as well as in charity work, environment and disaster relief /

\section{Source}

Abdullah, 2006; Afzal, Akram, Akram \& ljaz , 2010; Bickerstaffe \& Ridgers, 2007; Brochado, 2009; Businessweek, 2001; Business Today India, 2015; Contardo \& Wensley, 2004; Corey, 1981; Delaney, 2005; EFMD, 2016; Gault, 2000; Gill, 2012; Hall, 2008; Higher Education Comission, 2013; Joseph \& Joseph, 1997; Kelley \& Gaedeke, 1990; Kolachi \& Wajidi, 2008; Kolachi \& Mohammad. 2013: Kolluru. 2011: Leieune. 2011: LeBlanc \& Nguven. 1994:

Figure 1: Academic \& Personal Development Activities of Business schools from Modern Literature

\section{Islamic Perspective on Academic \& Personality Development Activities of Modern Literature:}

Islam supports academic and personality development activities of modern literature as far as it is in accordance with Quran and Sunnah. Islam provides faith dimension in education for its follower where learning becomes a religious obligation. According to Islam, it is compulsory on every male and female to seek education throughout their lives (Al-Attas 1979; Ashraf, 1995; Karim, 1938; Maududi, 1980; Nasr 1985; Tibawi, 1972). Islam provides a broader perspective for teaching methodologies and new techniques of learning. It is evident from a hadith from Bukhari cited in Amir (2014) that train and teach your generation for future era in best possible ways as that era will not be same as your era and they should be well equipped for those times. Furthermore, new ways in industry, craft and war technologies are proved from prophetic traditions (Usmani, 2005). From this Islamic perspective, the new dynamics in academic and personality development activities identified in modern literature for competitiveness of business schools are justified.

Moreover, a fair evaluation system and plagiarism policy to create equity among students in business schools reflects Islamic principle that commands justice in any situation (Qur'an 16:90; Qur'an 5:8; Qur'an 4:58; Qur'an 5:1). Likewise, punctuality and educational discipline are the most important activities in Islamic Shariah (Amir, 2014). Furthermore, obedience, self-control; understanding; support for values; rules and responsibility are closely related to discipline. Teaching in small groups and attendance ensure discipline. Small groups reflect more attention to individual and helpful in participation of students that is also learnt from Prophet Muhammad's teachings who used to listen patiently to opinions and arguments 
(Mernissi, 1991).

Consultation in real sense is required for integrated course. Courses are integrated when there is communication between teachers and course developer that what other teacher would be teaching. Prophet (pbuh) used to consult his wives and companions on important matters that give the message of consultation and collaboration in every aspect of life. Quran also commanded the Prophet (pbuh) to consult his companions for decision making (Qur'an 3:159). Quran has a surah "Chapter 42" with the name "consultations." Quran teaches to conduct affairs by mutual consultation (Qur’an 42:36-38).

Islam encourages halal businesses and the basic tenets of entrepreneurship such as hard work, search for opportunities, risk-taking and innovation (Kayed \& Hassan, 2011). Hassan and Hipper (2014) referencing the Quran and hadith concluded that Islam teaches hard work. It is Islamic perspective that this universe is created for the benefit of all mankind, the resources are spread and responsibility is given to human beings to make use of them, to mold them, and to transform them according to their needs (Hassan \& Hipper, 2014). There is a hadith giving a message of doing hard work and earn even in extreme difficulty than to ask someone for your needs, discouraging the concept of not working in human life (Sahih Bukhari, Vol 2, Book 24, No 549). It would not be an exaggeration to refer Islam as a religion of entrepreneurship for the reason it not only encourage but demands productivity and hard work in context of earning for supporting family and society (Adas, 2006; Hassan \& Hipper, 2014; Kayed \& Hassan, 2011).

Extracurricular activities of competitive business schools enhance the classroom learning and improve physical and mental health. The basic aim of these activities is to develop leadership, teamwork and communication abilities. In this aspect, extracurricular activities (within the Islamic boundaries) are supported in Islam because collaboration and teamwork is appreciated in all activities of life. Prophet (peace be upon him) has stressed over working in groups with team spirit (Abdullah, Azmin \& Salleh, 2014).

Competitive business school offers counseling for students such as stress management, time management, art of living etc. Studies support religion as an effective part of counselling services. The studies reported that religion is dire important in counselling for its positive effect on decreasing stress (Graham, Furr, Flowers \& Burke, 2001; Stanley et al., 2011; Yong, Wiggins-Frame \& Cashwell, 2007). Hamdan (2008) pointed different dimensions of belief in Islam which may be applied in the counseling process focusing on a cognitive restructuring model. Further, Islam highly valued time management. In Quran when Allah swears upon something, it gives it importance and significance like Surah Al-Asr. In this surah, Allah swear upon "Asr" showing importance of time. Moreover, the hadith of Prophet Muhammad (saw) reported from Ibn Abbas (ra) in Bukhari narrated that the blessings which many people may lose are two i.e. health and free time of doing good (Baqi, 1995).

The concept of diversity in business schools for competitiveness is consistent with Page | 187 
Islamic perspective. Equality and justice in Islam favors diversity (49:13). Islamic teachings highlights constructive purpose of diversity in races, families and tribes that it is meant to know each other and providing no reason for any sort injustice or barrier among human beings. In the Quran, diversity among human being is explicitly described that Allah could make human beings as one community but he granted diversity $(5: 48)$, so this diversity is not without purpose (Muhtada, 2012). The example of diversity and its management comes from Prophet tradition of pluralism and multiculturalism. The Medina charter was drafted with consultation of various tribes of Medina, the 10,000 population of Medina was organized into 22 tribes with the equal rights of Muslims and non-Muslims (Muhtada, 2012). The example of diversity management also lies in time of 'Umar ibn al Khatab, where non-Muslims were employed in important state affairs such as finance and public administration (Muhtada, 2012).

Islam supports features of competitive business schools such as promoting students for association with voluntary projects and engagement of business school in fulfilling its obligations to society by investing in the local community. From Islamic perspective, human being is responsible for taking care of the universe (Qur'an 35:40) and to utilize resources in most efficient manner not only as a matter of ensuring positive future usage of resources, but also as a matter of faith (Yousri, 2005). This broader aspect provide framework for ethical and social responsibilities of business schools. Moreover, activities to develop leadership skills and promote teamwork in students are also consistent with Islamic perspective. Prophet Muhammad (pbuh) stated that "Every one of you is a shepherd and every one of you is responsible for what he is shepherd of" (Sahịh al-Bukhārī, 6719). Multilevel leadership is provided in Prophet tradition. Islam provides leadership roles to everyone whether it is provided at national level, society level or at home (Ather \& Sobhani, 2008).There are certain features of the modern leadership such as servant, participative, transformation, and ethical leadership models that are consistent with Islamic perspective of leadership (Ather \& Sobhani, 2008). Moreover, Islam also highly emphasizes on teamwork rather that individual motives achievement. In Sunon Al Tirmidhi, Prophet Mohammad (pbuh) clearly said that Hand of Allah is with the team (Ather \& Sobhani, 2008) showing the importance of teamwork. It can be concluded that Islam supports academic and personality development activities of modern literature as far as it is not violating the basic Islamic principles.

\section{Relationship of Academic, Personality Development Activities with Competitiveness of Business schools:}

Competitiveness is a word commonly used in corporate literature. It is discussed as a property showing how well a firm meets its customer needs in comparison to other firms offering similar product or service (Melnyk \& Yaskal, 2013; Li, Li, Skitmore, Wong, \& Cheng, 2009). Literature highly supports stakeholders' satisfaction as a measure of competitiveness (Bauk \& Jusufranic, 2014; Massawe, 2013; Schuurman, 1997). In education sector, students are considered as the primary stakeholders (Sallis, 2002). In various studies, academics activities were found to have a positive impact on students' satisfaction (Abdullah, 2006; Azal et al., 2009; Bauk, and Jusufranic, 2014; Brochado, 2009; Huang, 2009; Mai, 2005). Similarly, it was found that personality development activities also positively influence 
students' satisfaction (Abdullah, 2006; Afzal et al., 2009; Bauk, and Jusufranic, 2014; Bitner \& Zeithaml, 1996; Brochado, 2009; Huang, 2009).

\section{Theoretical Framework \& Hypothesis}

Based on extensive literature review, the study has developed the following theoretical framework and hypothesis:

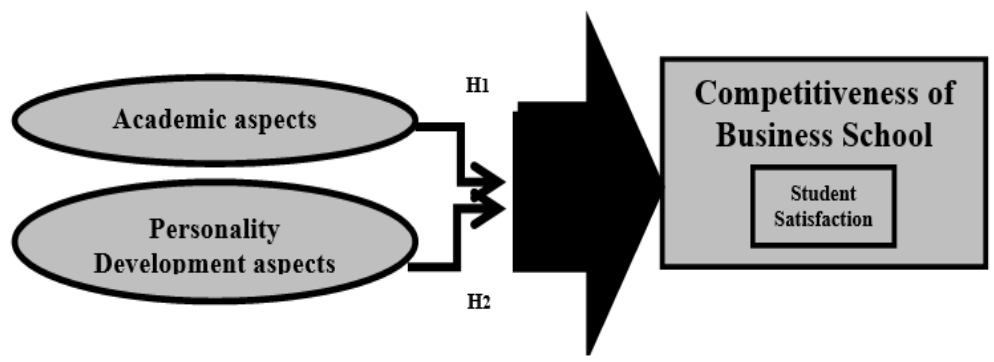

Figure 2: Theoretical Framework

$\mathrm{H1}$ : There is a significant and positive effect of academic activities on competitiveness of business schools

$\mathrm{H} 2$ : There is a significant and positive effect of personality development activities on competitiveness of business schools

\section{RESEARCH METHODOLOGY}

The population of the study consists of 3669 students of business schools associated with universities recognized by Higher Education Commission (HEC). A sample of 361 students was calculated using formula given by Yamane (1967). The sampling technique used in the study was stratified random sampling procedure. The study used proportionate allocation technique for sampling. The questionnaires returned after the distributions were 354 out of 361 , showing a response rate of $98 \%$. Furthermore, confidentiality was assured to the participants. Data was collected through self-administered questionnaire. The choices ranged between 1 (represented strongly disagree) and 5 (represented strongly agree).

\section{Analysis \& Results}

Descriptive Statistics, Reliability, Correlation and Confirmatory Factor analysis

The descriptive statistics, reliability along with correlation values are given in Table 1. The values for Cronbach alpha for the constructs academic activities, personality development activities and competitiveness of business schools are $0.916,0.90$ and 0.70 respectively. All the values lies within acceptable range, ensuring the reliability of research instrument. Pearson correlation was applied in the study showing that there is a significant positive relation of academic development activities $(\mathrm{r}=0.848)$ and personal development activities $(\mathrm{r}=0.840)$ with competitiveness of business schools. 
IBT Journal of Business Studies (IBT-JBS) Volume 15 Issue 2 December 2019

Table 1: Descriptive Statistics, Reliability \& Correlation

\begin{tabular}{|c|c|c|c|c|c|c|c|}
\hline S.No & & Mean & SD & $\begin{array}{l}\text { Cronbach } \\
\text { alpha }\end{array}$ & 1 & 2 & 3 \\
\hline 1 & $\begin{array}{l}\text { Academic } \\
\text { activities }\end{array}$ & 2.57 & 0.73 & 0.916 & 1 & & \\
\hline 2 & $\begin{array}{l}\text { Personality } \\
\text { development } \\
\text { activities }\end{array}$ & 3.02 & 0.93 & 0.90 & $0.808 * *$ & 1 & \\
\hline 3 & $\begin{array}{l}\text { Competitiveness } \\
\text { of business } \\
\text { schools }\end{array}$ & 2.62 & 0.58 & 0.70 & $0.848 * *$ & $0.840 * *$ & 1 \\
\hline
\end{tabular}

Confirmatory factor analysis was conducted using AMOS 16. The hypothesized three-factor model is shown in Figure 3 followed by Table 2. The value of goodness of fit indices normed chi-square, GFI, AGFI, CFI, NFI, RMSEA are 2.77, 0.86, $0.82,0.86,0.92$ and 0.076 respectively. All the values fall within the generally accept limit showing model is fit.

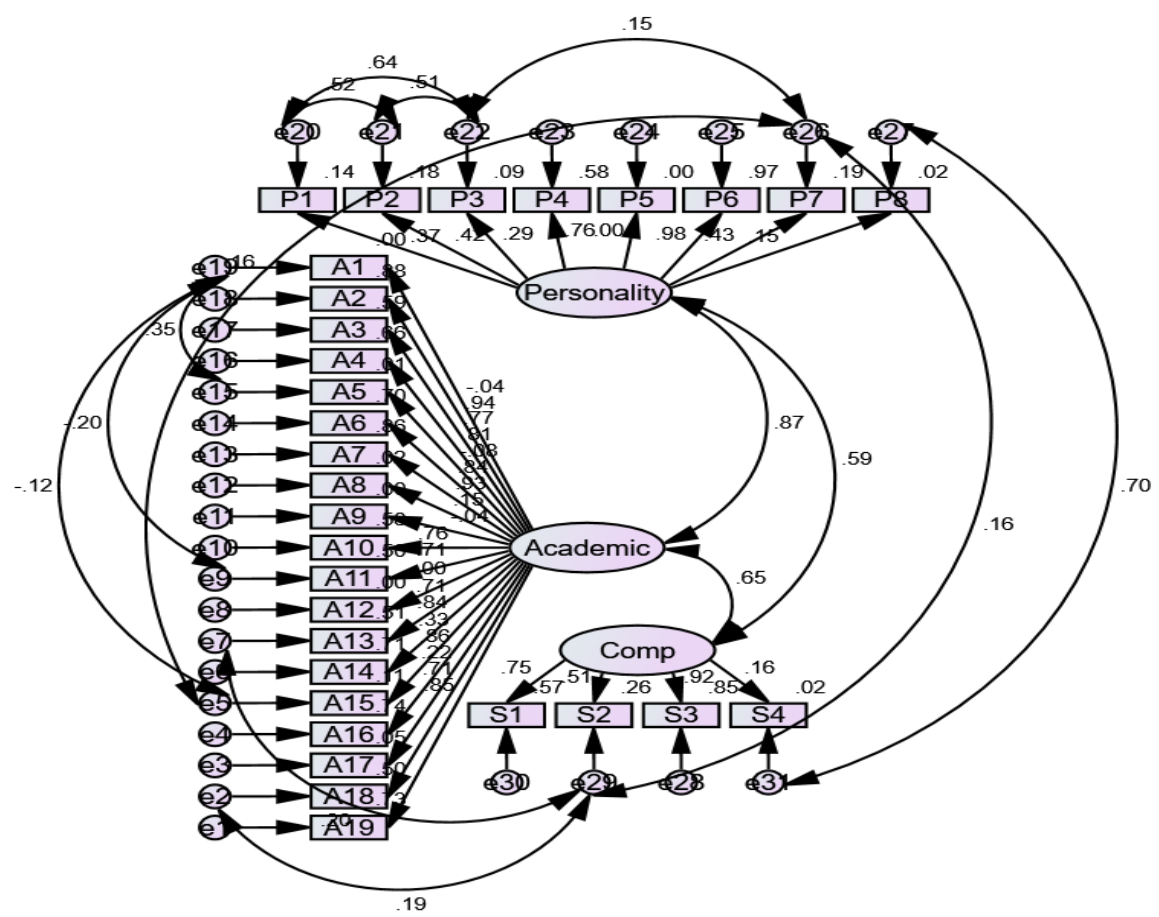

Figure 3: The Factor Model (CFA) 
IBT Journal of Business Studies (IBT-JBS) Volume 15 Issue 2 December 2019

Table 2: Summary of Measurement Model

\begin{tabular}{|l|l|l|l|l|l|l|l|}
\hline Model & $\begin{array}{l}\text { Normed Chi } \\
\text { square } \\
\text { (X2/df) }\end{array}$ & P-value & GFI & AGFI & CFI & NFI & RMSEA \\
\hline Study model & 2.77 & 0.00 & 0.86 & 0.82 & 0.86 & 0.92 & 0.076 \\
\hline $\begin{array}{l}\text { Recommended } \\
\text { Value }\end{array}$ & $<3$ & $>0.05$ & $0.8-0.9$ & $0.8-0.9$ & $0.8-0.9$ & $0.8-0.9$ & $<0.080$ \\
\hline
\end{tabular}

\section{Hypothesis Testing}

Further, multiple regression analysis was applied to investigate the relationship between independent and dependent variables given in Table 3. The value of $\mathrm{R}$ square is 0.788 for the multiple regression model showing that $78.8 \%$ variation in dependent variable (competitiveness of business schools) is caused by explanatory variables i.e. academic development activities and personal development activities. The value of $F$ statistics is 653.35 showing overall model is fit. The value of beta for academic development activities is 0.487 having t-value equal to 11.680 and $p$-value $=0.000$ depicting that 1 percent increase in academic development activities will lead to increase in competitiveness of business schools by $48.7 \%$. The value of beta for personal development activities is 0.447 having t-value equal to 10.730 and $\mathrm{p}$-value $=0.000$ depicting that 1 percent increase in personal development activities will lead to increase in competitiveness of business schools by $44.7 \%$. On the basis of these results, there is a significant positive relationship of academic and personal development activities with competitiveness of business school; hence $\mathrm{H} 1$ and $\mathrm{H} 2$ are accepted.

Table 3: Results of Regression Analysis

\begin{tabular}{|l|l|l|l|l|l|}
\hline \multicolumn{2}{|c}{ Model 1 } & R & R Square & $\begin{array}{l}\text { Adjusted R } \\
\text { Square }\end{array}$ & $\begin{array}{l}\text { Std. Error of } \\
\text { the Estimate }\end{array}$ \\
\cline { 3 - 6 } & & $0.888 \mathrm{a}$ & 0.788 & 0.787 & 0.26929 \\
\hline & Sum of Squares & Df & Mean Square & F & Sig \\
\hline Regression & 94.758 & 2 & 47.379 & 653.351 & $.000 \mathrm{a}$ \\
\hline Residual & 25.453 & 351 & .073 & & \\
\hline Total & 120.211 & 353 & & & Sig. \\
\hline $\begin{array}{l}\text { Constructs } \\
\text { Cnstandardized } \\
\text { Coefficients }\end{array}$ & Standardized Coefficients & T & \\
\hline $\begin{array}{l}\text { Academic } \\
\text { activities }\end{array}$ & 0.389 & Std. Error & Beta & & 0.000 \\
\hline $\begin{array}{l}\text { Personality } \\
\text { development } \\
\text { activities }\end{array}$ & 0.281 & 0.033 & 0.487 & 11.680 & 0.000 \\
\hline
\end{tabular}




\section{DISCUSSION}

The study attempted to investigate the impact of academic development activities and personality development activities on competitiveness of business schools. The findings indicated that there is a significant positive effect of academic activities on competitiveness of business schools. From perspective of students, business should offer wide range of programs and courses, programs with more flexible structure such as evenings, weekend's classes or online classes etc. and market relevant curriculum. The students expect from business schools to provide current materials in class other than textbooks and reviews coursework frequently. Further, small number of students in a class is preferable for effective learning. The competitiveness of business school will enhance when e-business, International business, entrepreneurship, analytical skills, advanced computer skills and technological tools are included in curriculum. Students seek individual attention and want that courses are taught in an interrelated or interconnected manner. Industry related assignments and projects are preferred for practical learning in business schools. Student's perception is that fair assessment and grading criteria, error free record keeping, strict attendance policy and plagiarism policy should be adopted in business schools. Likewise, new ways of teaching methodology aided with technological tools such as live case study methods, advanced computer simulation methods, learning through games and simulated trading areas are valued by students. Student's preparation before class also reflects the competitiveness of business schools and quality of its academics.

The findings also indicated that there is a significant positive effect of personality development activities on competitiveness of business schools. Students consider personality development activities important for business school such as interpersonal \& soft skills development, extracurricular activities, leadership and teamwork development, counseling such as stress management, time management and various other activities. Business school efforts to instill diversity, social responsibility, ethical values and promoting students for association with voluntary projects are valued by students. Moreover, engagement of business school in fulfilling its obligations to society by investing in the local community as well as in charity work, environment and disaster relief also positively influence competitiveness of business school from students' perspective.

The results of the study that academic development activities and personality development activities positively influence competitiveness of business schools are consistent with studies of Huang, Militaru, Deselnicu and Pollifroni (2015), Kalpana (2012), Owino (2012), Ravindran \& Wang, Tseng \& Wang, (2011), Wei (2009) and Zhou (2016). Moreover, the positive effect of academic development activities and personality development activities are also in line with Islamic perspective. Islam provides a strong foundation of faith for learning or academics and made it compulsory on every male and female to seek education throughout their lives (Al-Attas, 1979; Ashraf, 1995; Karim, 1938; Maududi 1980; Nasr, 1985; Tibawi, 1972). The modern ways of learning is justified in Islam as far it is in line with Islamic principles. It is evident from a hadith cited in (Amir, 2014) that to train and teach your generation for future era in best possible ways as that era will not equal 
to yours and they should be well equipped for that times. Further, activities such as fair assessment and grading criteria, error free record keeping, strict attendance policy, plagiarism policy is in line with the Islamic principle of justice in Quran (Qur'an 16:90; Qur'an 5:8). The concept of equality and justice in Islam also favors diversity (Qur'an 49:13 )). The example of diversity and its management lies in Islamic tradition when Medina charter was drafted with consultation of various tribes of Medina and in times of Umar ibn al Khatab, non-Muslims were employed in important state affairs such as finance and public administration (Muhtada, 2012). Furthermore, Amir (2014) highlighted that Islam directs toward discipline and the traits such as obedience, self-control; understanding; support for values; rules and responsibility are closely related to discipline. Teaching in small groups and attendance can ensure discipline in business schools and reflect more attention to individual and help in participation of students that is also reflected in Prophet Muhammad's teachings who used to listen patiently to opinions and arguments (Mernissi, 1991). It is also connected to another aspect of academics i.e. integrated coursework which require consultation in real sense. Prophet (PBUH) used to consult his wives and companions on important matters and Quran also commands mutual consultation (Qur'an 3:159, Qur'an 42:36-38). Similarly, Islam also encourages halal businesses and the basic tenets of entrepreneurship such as hard work, search for opportunities, risk-taking and innovation (Kayed and Hassan 2011; Hassan and Hipper, 2014). It is further supported in a hadith with a message of doing hard work and earning even in extreme difficulty than to ask someone for your needs (Sahih Bukhari, Vol 2, Book 24, No 549). Thus, Islam is a religion of entrepreneurship for the reason it not only encourage but demands productivity and hard work in context of earning to support family and society (Adas, 2006; Hassan \& Hipper, 2014; Kayed \& Hassan, 2011). Moreover, Prophet (peace be upon him) has stressed over working in groups with team spirit (Abdullah, Azmin and Salleh (2014). Prophet Mohammad (pbuh) clearly said that Hand of Allah is with the team (Ather \& Sobhani, 2008). Leadership is explicitly acknowledged in Islam and Prophet Muhammad (pbuh) stated that "Every one of you is a shepherd and every one of you is responsible for what he is shepherd of" (Sahih Al Bukhari, 6719). Islam provides leadership roles to everyone (Ather \& Sobhani, 2008). Other personality development activities within competitive business schools such as students counselling is also justified from Islamic perspective and various studies support positive role of religion in counselling (Graham, Furr, Flowers, \& Burke, 2001; Hamdan, 2008; Hasyimi, 1986; Stanley et al., 2011; Yong, Wiggins-Frame \& Cashwell, 2007). Time management is also highly valued in Islam (Baqi, 1995). In Surah Al-Asr, Allah swears upon Asr (time) showing its importance. Islamic paradigm also supports all those activities in business schools that enhance social responsibility in students. From Islamic perspective, human being is responsible for taking care of the universe (Qur'an 35:40) and it is also a matter of faith (Yousri, 2005). In the present scenario, where marketplace is marked by fraud and corruption and world is finding solution for the problems through business ethics, Islamic framework of the ethics in business can be very useful in solving the emerging ethical problems of corporate world. In fact, Islamic framework of the ethics in business is rich in providing practical solutions as compared to material based frameworks (Ali, 2014). 


\section{CONCLUSION AND FUTURE RESEARCH}

The study concluded that academic and personal development activities have a positive impact on competitiveness of business schools. It was also found that there is a misconception about Islam regarding business and economic perspective. Islam supports businesses and its education and provides a comprehensive framework that embodies moral and social values leading to a prosper society in long-term. The activities of academic and personality development in modern literature to increase the competitiveness of business schools are supported by Islamic perspective as far as it is within Islamic boundaries. Future studies are directed to cover other activities required for competitiveness of business schools and its relevance from Islamic perspective.

\section{REFERENCES}

Abdullah, F. (2006). The development of HEdPERF: A new measuring instrument of service quality for the higher education sector. International Journal of Consumer Studies, 30(6), 569-81.

Abdullah, F., Azmin, A. K., \& Salleh, N. H. (2014). Developing graduates' collaboration skill based on Islamic perspective through integrated multidisciplinary course in the built environment. International Journal of Social Science and Humanity, 4(2), 117-121.

Adas, E. B. (2006). The making of entrepreneurial Islam and the Islamic spirit of capitalism. Journal for Cultural Research, 10(2): 113-137.

Al-Attas, M. (1979). Aims and objections of Islamic education. Hodder and Stoughton: King Abdul Aziz University; Jeddah: Saudi Arabia.

Ali, A.J. (2014). Business ethics in Islam. UK: Edward Elgar Publishing Limited.

Amir, D. (2014). On time and discipline in Islam (Analysis towards purpose of Islamic education). Al-Ta lim Journal, 21(3), 220-226.

Ather, S.M., \& Sobhani, F.A. (2008). Managerial leadership: An Islamic perspective. IIUC Studies, 4, 7-24.

Afzal, W., Akram A., Akram M.S., \& Ijaz A. (2010). On students' perspective of quality in higher education. Paper presented at 3rd International Conference on Assessing Quality in Higher Education, Lahore, Pakistan. Retrieved from http:// www.icaqhe2010.org/Papers\%20published\%20in\%203rd\%20ICAQHE\%20 2010/28-Dr\%20Waheed\%20Afzal.pdf

Ashraf, S. A. (1995). Basic principals in the formulation of curriculum for tertiary education with specific reference to humanities. Muslim Education Quarterly, 13(1), 5-11.

Bauk, S., \& Jusufranic, J. (2014). Competitiveness in higher education in terms of the level of students' satisfaction with e-learning in blended environment. Montenegrin Journal of Economics, 10(1), 25-42.

Baqi, A. F. (1995). Al-Lu'lu' Wal-Marjan: A collection of agreed upon Ahadith from AlBukhariand Muslim (1st ed.). Riyadh-Saudi Arabia: Dar-us-Salam Publications.

Bennis, W. G., \& O'Toole, J. (2005). How business schools lost their way. Harvard Business Review, 83(5), 96-104

Bickerstaffe, G., \& Ridgers, B. (2007). Ranking of business schools. Journal of 
Management Development, 26 (1), 61-66.

Bitner, M.J., \& Zeithaml, V.A. (1996). Services marketing. New York: McGrawHill.

Brochado, A. (2009). Comparing alternatives instruments to measure services quality in higher education. Quality in Higher Education, 17(2), 1-30.

Businessweek. (2001). Business week guide to the best business schools (7th ed.). US: McGraw-Hill Companies, Inc.

Business Today India, (2015). India's best bschools. Retrieved from http://bschools. businesstoday.in/

Contardo, I., \& Wensley, R. (2004). The Harvard business school story: Avoiding knowledge by being relevant. Organization ,11, 211-31

Corey. R.E. (1981). Case method teaching. Boston, MA: Harvard Business School Press.

Delaney, A. (2005). Expanding students' voice in assessment through senior survey research. American Institutional Research Professional File, 6, 1-19.

EFMD. (2016). The EQUIS quality standards. Retrieved from www.efmd.org.

Friedman, M. (1962). Capitalism and freedom. University of Chicago Press.

Gault, J. (2000). Effects of business internships on job marketability: The employers' perspective. Education + Training 52 (1), 76-88.

Gill, G. S. (2012). Management education in India: A case study of selected b-schools (Ph.D. dissertation). Punjab College of Technical Education Baddowal, Ludhiana.

Graham, S., Furr, S., Flowers, C., \& Burke, M. (2001). Religion and spirituality in coping with stress. Counseling and Values, 46(1), 2-13.

Gumusay, A. A. (2015). Entrepreneurship from an Islamic perspective. Journal of Business Ethics, 130(1), 199-208.

Hall, S. (2008). Geographies of business education: MBA programmes, reflexive business schools and the cultural circuit of capital. Transactions of the Institute of British Geographers, New Series, 33(1), 27-41.

Hamdan, A. (2008). Cognitive restructuring: An Islamic perspective. Journal of Muslim Mental Health, 3, 99-116.

Huang, P.Y., Wang, C.C., Tseng, Y.Y., \& Wang, R.J. (2011). The impact of curriculum design on learning satisfaction. Journal of Information and Optimization Sciences, 32(3), 637-655.

Hassan, M. K., \& Hippler III, W. J. (2014). Entrepreneurship and Islam: An overview. Econ Journal Watch, 11(2), 170-179.

Hasyimi, Abd Hamid Muhammad (1986). Al-Tawjih wa al-Irsyad al-Nafsiyy. Jeddah: Dar al-Syuruq

Higher Education Comission (HEC) Pakistan. (2013).Quality and research based ranking of Pakistani HEIs 2013 ranking, methodology, criteria \& weights. Retrieved from http://www.hec.gov.pk/InsideHEC/Divisions/QALI/Others/ RankingofUniversities/Documents/Quality\%20and\%20Research\%20 Based\%20Ranking\%20of\%20Pakistan\%20HEIs_Updated.pdf

Huang, Q. (2009). The relationship between service quality and student satisfaction in higher education sector: A case study on the undergraduate sector of Xiamen University of China (Masters dissertation). Assumption University, Thailand.

Joseph, M. \& Joseph, B. (1997). Service quality in education: A student perspective. Quality assurance in education, 5(1), 15-19.

Page $\mid 195$ 
Karim, F. (1938). Al Hadith (Vol.1). The Book House. Lahore: Pakistan.

Kayed, R.N., \& Hassan, M. K. (2011). Islamic Entrepreneurship. NewYork: Routledge.

Kelley, C.A. and Gaedeke, R.M. (1990). Student and employer evaluation of hiring criteria for entry-level marketing positions. Journal of Marketing Education,1, 64-71.

Kolachi, N.A., \& Wajidi, A.Z. (2008). Business Education in Pakistan: Identifying weaknesses and suggesting improvements. East-West Journal of Economics and Business, 11(1), 157-178.

Kolachi, N. A., \& Mohammad, J. (2013). Excellence in business education (A "FRUCE" model for Higher Education Commission-Recognized business schools in Pakistan). American Journal of Business Education, 6(3), 311-320.

Kolluru, S. (2011). Rankings of Indian business schools: A statistical analysis. ASCI Journal of Management, 40(2), 101-112.

Koh, K. (2012). Enhancing university competitiveness through educational facilities [PowerPoint slides]. Retrieved from Ministry of science and technology Republic of Korea, OECD http://www.cele2012korea.com/eng/images/pdf/ Session0-2 e.pdf

LeBlanc, G., \& Nguyen, N. (1997). Searching for excellence in business education: An exploratory study of customer impressions of service quality. International Journal of Educational Management, 11(2), 72-79.

Lejeune, C. (2011). Is continuous improvement through accreditation sustainable? A capability-based view. Management Decision, 49(9), 1535-1548. Retrieved from www.emeraldinsight.com/0025-1747.htm

Li, Heng., Li, Vera., Skitmore, Martin .,Wong, Johnny Kwok Wai.,\& Cheng, Eddie W. L. (2009). Competitiveness factors: A study of the real estate market in China. Construction Management and Economics, 27(6), 567-579.

Melnyk, O., \& Yaskal, I. (2013). Theoretical approaches to concept of "competition" and competitiveness. Ecoforum Journal, 2(2), 8-12.

Mai, L. (2005). A comparative study between UK and US: The student satisfaction in higher education and its influential factors. Journal of Marketing Management, 21, 859-878.

Massawe, D. (2013). Customer satisfaction and complaints as a means of gaining a competitive advantage in hospitality industry. The Eastern African Journal of Hospitality, Leisure and Tourism, 1(1), 1-12.

Mintzberg, H. (1988). Crafting strategy. Harvard Business Review, 65 (1), 66-75.

Mernissi, F. (1991). The veil and the male elite. Camberidge, Massachusetts: Perseus Book.

Milner, S., Cousins, W., \& McGowan, I. (2016). Does all work and no play make a dull graduate? Perceptions of extra-curricular activities and employability. Journal of Perspectives in Applied Academic Practice, 4(1), 13-18.

Militaru G., Deselnicu, D., and Pollifroni M. (2015). An exploratory study of student satisfaction: The moderating role of digital technologies. Proceedings of the 9th International Management Conference, Management and Innovation for Competitive Advantage, November 5th-6th, 2015, Bucharest, Romania.

Maududi, Sayyid Abula'la. (1980). The Islamic law and constitution; translated by Khurshid Ahmad. Lahore: Islamic Publications Pakistan.

Muhtada, D. (2012). Managing workforce diversity: An Islamic perspective. 
Indonesian Journal of Islam and Muslim Societies, 2(1), 78-108.

Musselin, C. (2018). New forms of competition in higher education. SocioEconomic Review, 16(3), 657-683.

Musah, M.B. (2011). The culture of individualism and collectivism in balancing accountability and innovation in education: An Islamic perspective. International Journal of Sustainable Development, 2(8), 69-75.

Nasr, S. H. (1985). Ideals and realities of Islam. London: George Allen and Unwin.

Neelankavil, J. P. (1994). Corporate America's quest for an ideal MBA. Journal of Management Development, 13 (5), 38-52.

Owino, E. O. (2014). The influence of service quality and corporate image on customer satisfaction among university students in Kenya (Ph.D dissertation). University of Nairobi, Kenya.

QS World Ranking University. (2014). University rankings. Retrieved from http:// www.topuniversities.com/university-rankings

Qureshi, A.A. (2012). How do perceptions of the importance of service-quality determinants differ across key stakeholder groups in the Pakistan higher education sector? (M.Phil dissertation). Loughborough University.

Ravindran, S. D., \& Kalpana, M. (2012). Student's expectation, perception and satisfaction towards the management educational institutions. Procedia Economics and Finance, 2, 401-410.

Rice, G. (1999). Islamic Ethics and Implications for Business. Journal of Business Ethics, 18(1), 345-358.

Sallis, E. (1993). Total quality management in education. Philadelphia PA: Kogan Page.

Shattock, M. (2003). Managing successful universities. Maidenhead: Open University Press.

Schuurman, H. (1997). Quality management and competitiveness: The diffusion of the ISO 9000 standards in Latin America and recommendations for government strategies. Santiago: Division of Production, Productivity and Management of the Economic Commission for Latin America and the Caribbean, United Nations.

Scott, S. D. (2012). Sailing blue oceans in search of blue ribbons: A case study of the application of reconstructionist strategy in collegiate business schools (Ph.D dissertation).University of Tennessee, Knoxville.

Stanley, M. A., Bush, A. L., Camp, M. E., Jameson, J. P., Philipss, L. L., Barber, C. R., et al. (2011). Older adults' preferences for religion/spirituality in treatment for anxiety and depression. Aging and Mental Health, 15(3), 334-343.

Thaib, L., \& Chepa, B. (2014). Islamic business leadership modelling for sustainable development. International Journal of Multidisciplinary Academic Research, 2(1), 25-37.

The economist. (2016). Which MBA: methodology 2016. Retrieved from http:// www.economist.com/whichmba

Times Higher Education. (2016). Asia university rankings 2016 methodology. Retrieved from https:/www.timeshighereducation.com/world-universityrankings/2016/regional-ranking-methodology

Tibawi, A. L. (1972). Islamic education. London: Luzac and Company Ltd.

Usmani, M. M. T. (2005). Islam and modernism. Adam Publishers.

Wei, H.R. (2009) The investigation on the degree of satisfaction of students in

Page | 197 
normal university. Human Resource Management, 4, 118-120.

World Bank.(2000). Higher education in developing countries perils and promises. Retrieved from http://siteresources.worldbank.org/EDUCATION/ Resources/278200 1099079877269/547664-1099079956815/peril_promise _ en.pdf

World Bank Group. (2015). Accelerating growth through skills and knowledge: An evaluation of the World Bank Group's support for higher education. Retrieved from http://documents.worldbank.org/curated/en/511311467997571440/ pdf/96834-REVISED-Box393176B-PUBLIC-Approach-Paper-HigherEducation.pdf

WorldEconomic Forum.(2014). The global competitiveness report2014-2015.http:// www3.weforum.org/docs/WEF GlobalCompetitivenessReport 2014-15.pdf

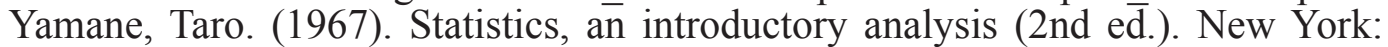
Harper and Row.

Young, J. Scott, Wiggins-Frame, M., \& Cashwell, Craig S. (2007). Spirituality and counselor competence: A national survey of American counseling association members. Journal of Counseling \& Development, 85, 47-52.

Yousri, A.R. (2005). Sustainable development: An evaluation of conventional and Islamic perspectives. In M. Iqbal, Islamic perspectives on sustainable development (pp. 22-57). New York: Palgrave Macmillan.

Zhou, H.Y. (2016) Empirical Study on University Curriculum Satisfaction of University Graduates. Open Journal of Social Sciences, 4, 132-137. Retrieved from http://dx.doi.org/10.4236/jss.2016.41017 